\title{
The influence of fuel oil prices on profitability with corporate social responsibility as moderating variable (Empirical study of companies in oil and gas mining industry listed on Indonesia Stock Exchange)
}

\author{
Fitriaty; Tona Aurora Lubis; Ningsi Trilianah \\ Faculty of Economics and Business, University of Jambi \\ e-mail correspondence: fitriaty.fy27@gmail.com
}

\begin{abstract}
This study aims to analyze the effect of fuel prices on profitability with Corporate Social Responsibility (CSR) as a moderating variable in the mining industry companies listed in Indonesia Stock Exchange 2013-2016 period. This study uses Partial Least Square (PLS), which aims to predict the relationship between variables. Measurement model used validity and reliability, while the structural model used to test causality. The results of this study indicate that the price of fuel oil has no significant effect on the profitability of the company. Corporate Social Responsibility (CSR) as a moderating variable can affect the relationship of the price of fuel on profitability.
\end{abstract}

Keywords: Fuel price, Profitability, Corporate social responsibility, Partial least square

JEL classification: G23, M14, M21

\section{INTRODUCTION}

The fuel oil is an important thing in a country, especially in all economic activities. The fuel oil takes a role in almost all economic activity in Indonesia. Fuel oil is used as an operational tool in industries in Indonesia because oil fuel can be used for various purposes of the company's operations. The impact of this oil price change is a change in the operational costs that will result in changes in the rate of return of investment activity. The decline in oil prices will certainly have a huge effect on the economy, so it will certainly alleviate the burden of lower middle society and also for the business world. The fuel oil policy that is fluctuating occurs in Indonesian Government since 2013 till 2016.

Table 1. Fuel prices on gasoline and solar in Indonesia, Year 2013-2016

\begin{tabular}{lcc}
\hline Date & $\begin{array}{c}\text { Gasoline Price } \\
\text { /Liter (Rp) }\end{array}$ & $\begin{array}{c}\text { Solar Price /Liter } \\
(\mathrm{Rp})\end{array}$ \\
\hline June 22, 2013 & 6,500 & 5,500 \\
November 18, 2014 & 8,500 & 7,500 \\
January 1, 2015 & 7,600 & 7,250 \\
January 19, 2015 & 6,700 & 6,400 \\
March 1, 2015 & 6,800 & 6,400 \\
September 01, 2015 & 7,300 & 6,900 \\
January 5, 2016 & 6,950 & 5,650 \\
April 1 - December 31, 2016 & 6,450 & 5,150 \\
\hline
\end{tabular}

Source: www.bphmigas.go.id 
During 2013 to 2016, the volatile fuel price policy occurred in the Indonesian government. On November 18, 2014, subsidized fuel prices increased $31 \%$ for gasoline and $36 \%$ for solar. Two months later, on January 1, 2015, the government made a new policy for subsidized fuel. There was a price decline for $11.8 \%$ for gasoline and $3.4 \%$ for solar.

Eighteen days later, precisely on January 19, 2015, the price of subsidized fuel declined again. In the following year, precisely on January 5, 2016 gasoline and solar prices experienced a decline. Furthermore, three months later gasoline and solar prices also declined.

According to Husnan (2001) that Profitability is the ability of a company to generate profits at the level of sales, assets, and capital stock. Companies in general aims to maximize profit. In terms of pursuing these objectives, the company will focus on operations to gain the maximum profit so that companies do the exploitation of natural resources and social society in an uncontrolled manner. This will lead to environmental damage that ultimately interfere with human life. Corporate social responsibility should be based on triple bottom lines, which include financial, social, and environmental issues because financial conditions alone will not be enough to ensure sustainability. Global Impact Initiative (2002) calls this understanding with 3P (profit, people, planet), that business objectives are not only looking for profit (profit), but also the welfare of the person (people) and ensure the sustainability of the planet (Dahli and Siregar, 2008) .

CSR activities in Indonesia are implemented in various approaches such as corporate charity, corporate generosity, corporate social relations, and community development. CSR look at helping companies improve their financial performance and access to capital, improve brand image and sales, maintain quality of work strength, improve decision-making on critical issues, handle risks more efficiently and reduce long-term costs . CSR does not provide financial results in the short term. However, CSR will deliver results either directly or indirectly, to the company's future finances.

The ability of companies to generate profits (Jessika Zarlia and Hasan Salim, 2014) revealed that Profitability and CSR positively affect the value of the company. The greater level of profitability indicates the company is able to earn greater profits, so the company is able to increase its social responsibility and social responsibility disclosure in its wider annual report (Kamil and Herusetya, 2012).

In practice, profitability is an indicator of management performance shown through profit generated during managing corporate wealth (Soelistyoningrum, 2011). Profitability can be measured using profitability ratios that will generate profits through ratios such as Profit Margin, ROA (Return on Assets), ROE (Return on Equity ), ROI (Return on Investment), and EPS (Earning Per Share), (Brigham and Houston, 2010).

The phenomenon that occurred in the results of previous research there are some government policies in lowering or raising the price of fuel oil that affects the profitability of the company. In addition, the impact that occurs would affect all operations and activities of corporate social responsibility.

Lasut and Debby (2009) stated that the price of fuel oil has a very significant effect on the amount of income received so that the government's active role in controlling oil price increases is needed. Furthermore, Suarjana (2011) stated that the government's policy in lowering the price of fuel caused a negative market reaction which is indicated by the decrease of income/result from the company. Meanwhile, Latif (2015) states that the impact is not only applicable to the general public or daily needs but also to the company. Many companies will complain and cut budgets because 
of the reduced profits they get so as not to close the possibility of companies will raise the price of operational goods and other budgets.

Rosiana (2013) and Nistantya (2011) stated that corporate social responsibility has a significant effect on the profitability of the company. While Nugroho (2012) states that corporate social responsibility has no significant effect on the profitability of the company. In addition, as a reciprocal influence, Sitepu (2003), Pristiwati (2011), and Badjuri (2011) stated that profit significantly influences CSR disclosure. Meanwhile, Sembiring (2006), Nur (2012), and Marinda (2014) stated that profit has no significant effect on CSR disclosure.

Based on the description of the above background explained that there is the influence of fuel prices on profitability and Corporate Social Responsibility (CSR) from the company or vice versa. Therefore, in this study the researchers wanted to find out a fuel price in year period 2013-2016 have an influence on the profitability of oil and gas companies? and a Corporate Social Responsibility (CSR) as a moderating variable can influence the relationship between oil fuel price and profitability of oil and gas company positively?

In accordance with the problems in above there are several objectives to be persuied nature of this study, namely to examined the impact of fuel prices on the profitability of oil and gas companies in year period 2013-2016 and the influence of Corporate Social Responsibility (CSR) as moderating variable on the relationship between the price of fuel oil to the profitability of oil and gas companies.

Fuel is any material that can be converted into energy. Usually the fuel contains heat energy that can be released and manipulated. Fuel oil as an important commodity used by almost everyone, its price can affect the performance of Indonesian economy. Therefore, setting fuel oil prices is very important. Not infrequently the pricing of fuel oil can burden the poor and always followed by rising prices of other materials (source: id.wikipedia.org).

According to Fahmi (2012), profitability ratio is beneficial to show the success of the company in generating profit. Potential investors will thoroughly analyze the smoothness of a company and its ability to profit (profitability), as they expect dividends and market prices from their shares. This ratio is intended to measure the efficient use of company assets.

Profitability ratios measure the effectiveness of management shown through the profit (profit) generated on sales and investment companies. (Gaspersz, 2011). This ratio measures the overall effectiveness of management that is directed to the size of the profits gained in relation to sales or investment. (Fahmi, 2012). Profit Margin ratio, Return on Assets (ROA), Return on Investment (ROI), Return on Equity (ROE) and Earning Per Share (EPS). (Sutrisno, 2009).

According to Sulistyo (2011), corporate social responsibility (Corporate Social Responsibility) is an organization's obligation to act in a way that is intended to serve the interests of their own and the interests of stakeholders. Awareness of the importance of practicing CSR is a global trend in line with the increasing global public awareness of eco-friendly products and is produced with due regard to social principles and human rights principles.

\section{RESEARCH METHOD}

This study uses a quantitative approach. Types of data used by the authors in conducting this research is to use secondary data in the form of annual financial statements in oil and gas mining companies listed on the Indonesia Stock Exchange. 
The financial statements used are those that have accounting year ended December 31, 2013-2016. The research sample using purposive sampling technique that aims to sampling data source that is based with particular consideration.

The sampling criteria set by researchers include oil and gas mining companies listed in BEI for 2013-2016, providing a full annual report dated 31 December 2013 to 2016, having complete data related to the variables used in research.

The variables used in this study and the measurement are as follows:

a. Exogenous Variable

$\mathrm{X}=$ Fuel Price Oil

$\mathrm{X}=$ the change price per year 2013-2016

b. Endogen Variabel Endogen

$\mathrm{Y}_{1}=$ Return On Assets (ROA)

ROA $=\frac{\text { EarningBeforelnterestTax }(\text { EBIT })}{\text { Total Aktiva }}$

$\mathrm{Y}_{2}=$ Return On Investment (ROI)

ROI $=\frac{\text { EarningAfterTax }(E A T)}{\text { TotalAssets }}$

$\mathrm{Y}_{3}=$ Return On Equity (ROE)

$R O E=\frac{\text { Earning AfterTax }(\text { EAT })}{\text { Shareholders Equity }}$

c. Moderating Variable

$\mathrm{Z}=$ Corporate Social Responsibility (CSR)

$\mathrm{CSDI}_{\mathrm{j}}=\frac{\sum \mathrm{X}_{\mathrm{ij}}}{n j}$

\section{Data analysis method}

Partial Least Square Analysis (PLS) is a multivariative statistical technique that performs comparisons between multiple endogenous variables and multiple exogenous variables. PLS is one of the variance-based SEM statistical methods that can simultaneously perform testing of measurement models as well as structural models. (Hussein, 2015). The purpose of using PLS is to make predictions. Prediction is the prediction of relationships between variables. The measurement model is used for validity and reliability test, while the structural model is used for the test of quality (test with prediction model).

Partial Least Square (PLS) is a powerful analytical method because it is not based on many assumptions. Because the PLS method has its own advantages such as: the data should not have multivariate normal distribution (indicators with category scale, ordinal, interval until the ratio can be used on the same model) and sample size should not be large. Although PLS is used to confirm the theory, it can also be used to explain the presence or absence of latent variables. PLS can analyze as well as construct formed with reflexive indicator and formative indicator and this is not possible in Structural Equation Model (SEM) because it will happen unidentified model. (Noor, 2014).

The SEM-PLS model framework in this research is given in Figure 1 below: 


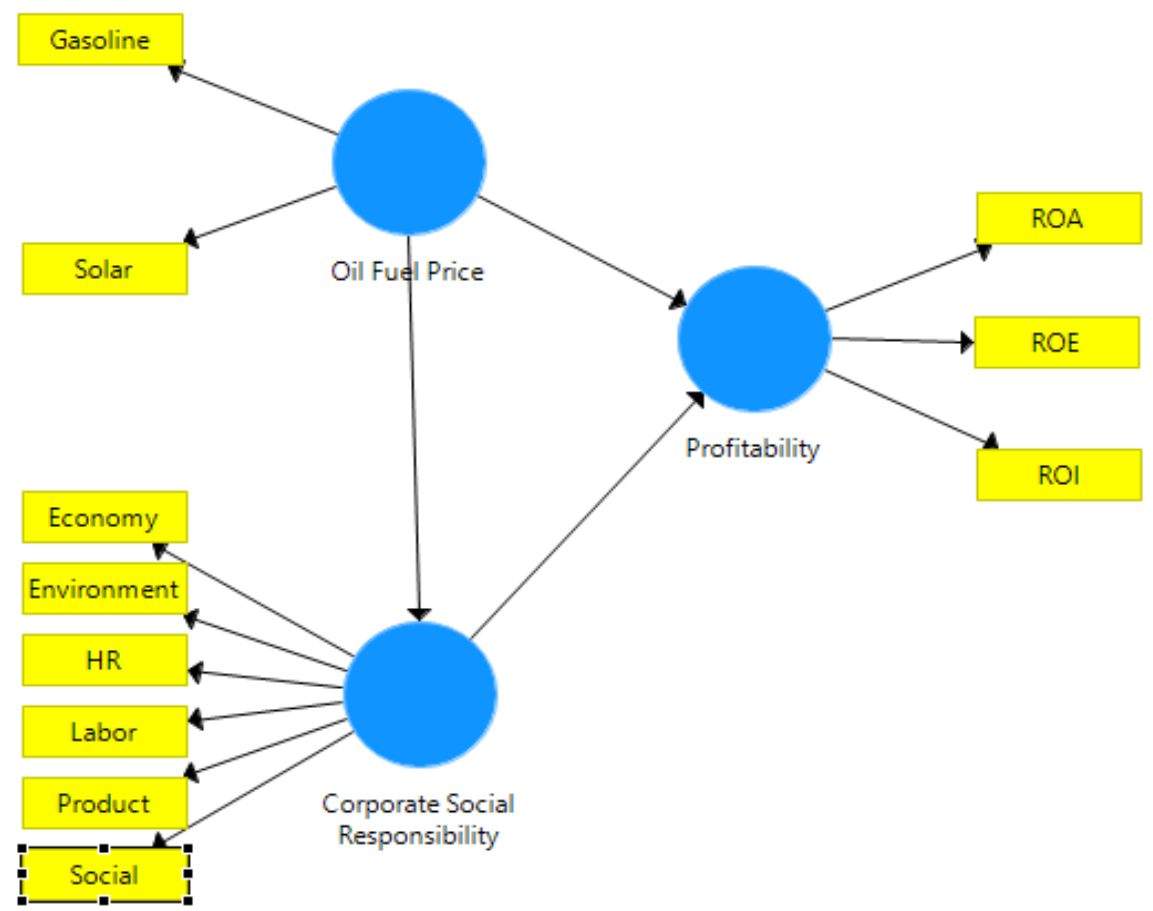

Figure 1. SEM-PLS model framework

\section{Hypothesis testing (resampling bootstraping)}

Hypothesis Testing $(\beta, \gamma$, and $\lambda)$ is done by Bootstrap resampling method developed by Geisser \& Stone. The test statistic used is t statistic or t test. Application of resampling methods, allowing free entry into force of the distributed data (distribution free) does not require the assumption of a normal distribution, and does not require a large sample (sample recommended minimum of 30). Testing is done by t-test, when obtained $\mathrm{p}$-value $\leq 0,05$.

Statistical hypothesis for outer model :

$\mathrm{H} 0: \lambda \mathrm{i}=0$

$\mathrm{H} 1: \lambda \mathrm{i} \neq 0$

Statistical hypothesis for inner model : exogenous latent variable to endogenous:

$\mathrm{H} 0: \mathrm{\gamma i}=0$

H1: yi $\neq 0$

Statistical hypothesis for structural model : exogenous latent variable to endogenous:

$\mathrm{H} 0: \beta \mathrm{i}=0$

$\mathrm{H} 1: \beta \mathrm{i} \neq 0$

Test statistics: t-test ; p-value $\leq 0.05$ (alpha 5\%); significant. If outter model is significant: the indicator is valid. If inner model is significant: there is significant influence. PLS does not assume normal distributed data: using resampling technique with Bootstrap method.

\section{RESULT AND DISCUSSION}

\section{Estimation Result}

The estimation of the SEM-PLS model between fuel prices, CSR and profitability is given in Figure 2 


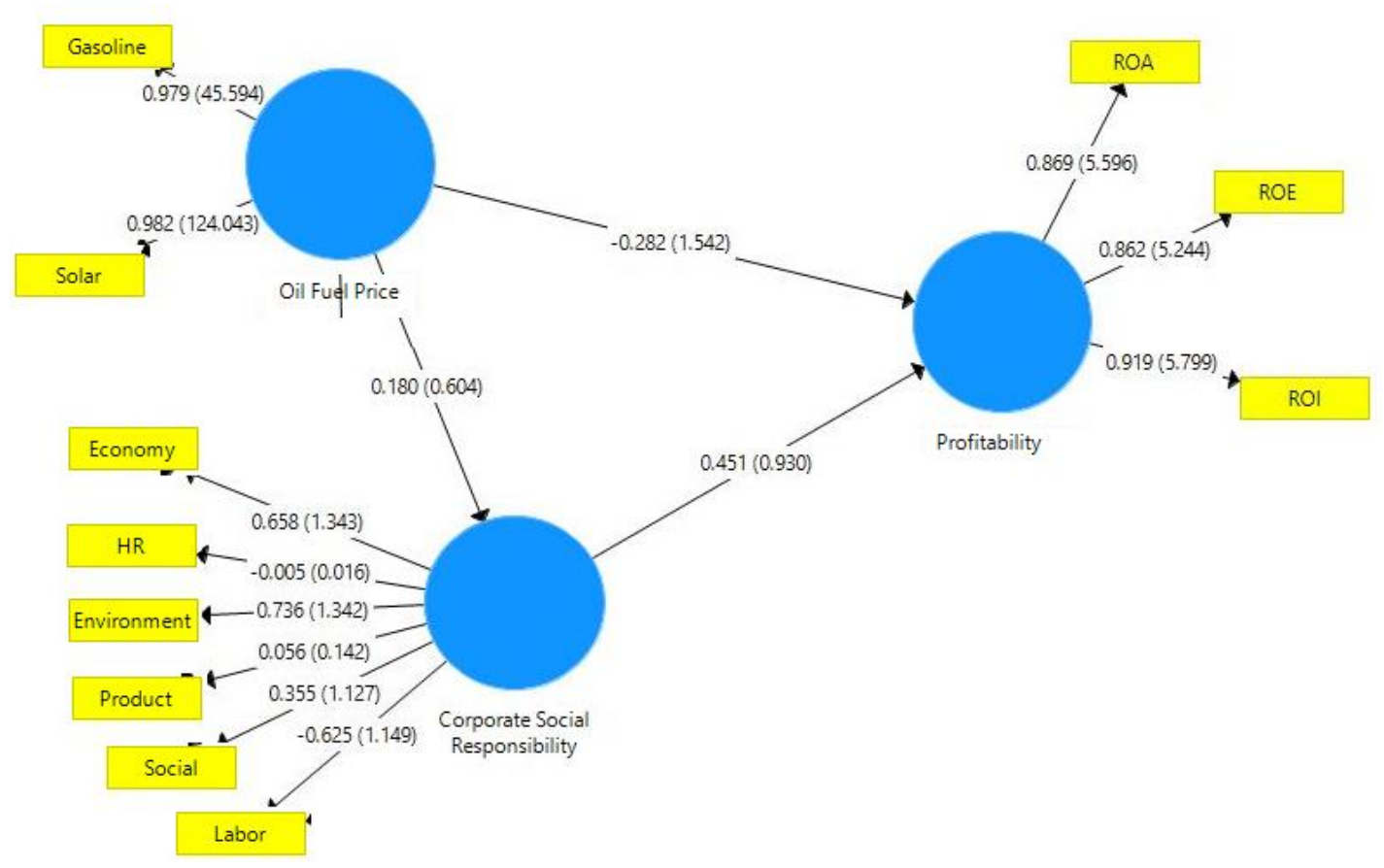

Figure 2. Estimation of the model between fuel prices, CSR and profitability (model 1)

From Figure 2, it can be seen that the items of HR (Human Right), Product, Social, and Labor have a loading factor value below 0.6. Therefore the four items must be removed from the model

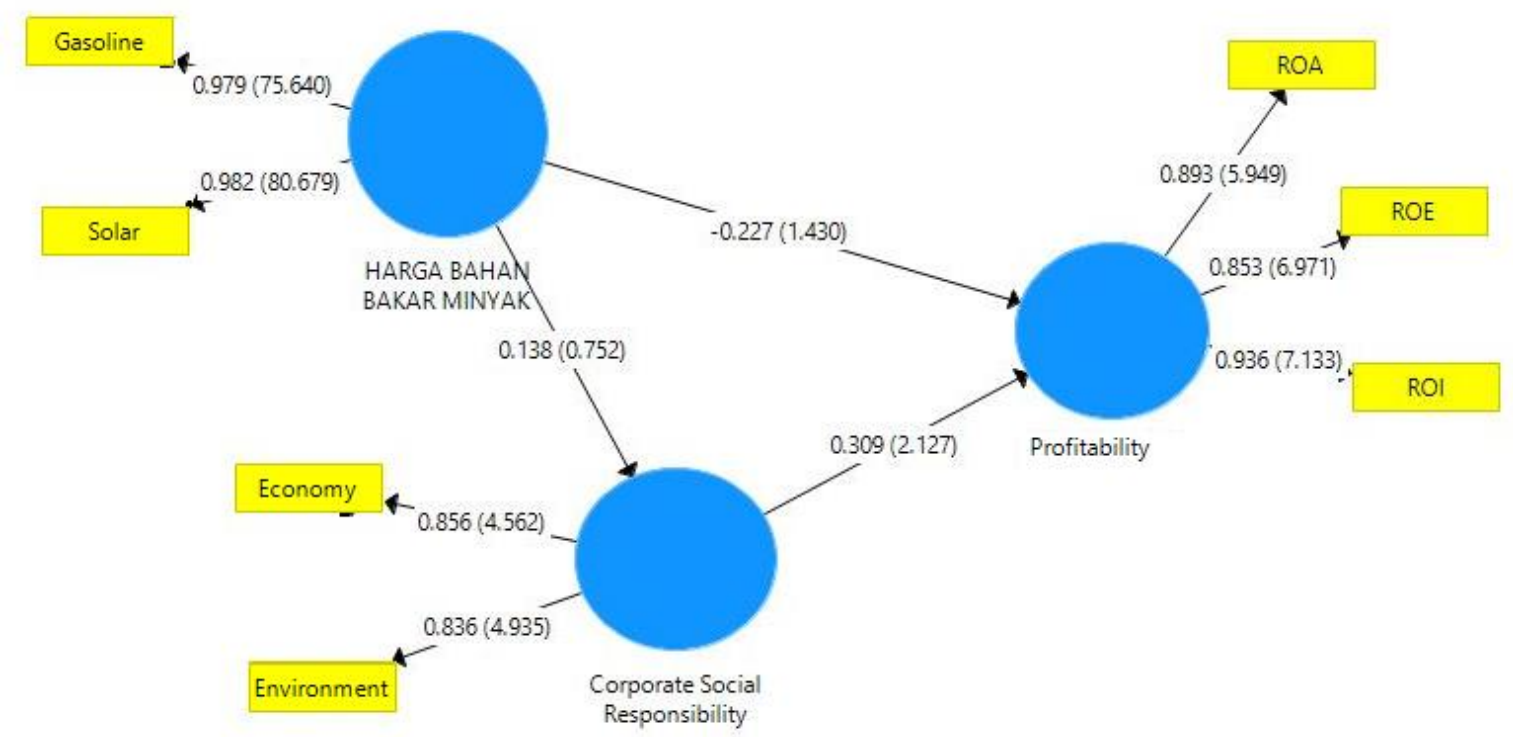

Figure 3. Estimation of the model between fuel prices, CSR and profitability (model 2)

Convergent validity of measurement model with reflexive indicator can be seen from correlation between score item/indicator with construct score. Individual indicators are considered reliable if they have a correlation above 0.70 . However, in the early stages, loading 0.50 to 0.60 is still acceptable. The output of the correlation output between the indicator and its construct as shown in the outer loading output is given in Table 2 below: 
Table 2. Outer Loadings

\begin{tabular}{lccc}
\hline & Oil Fuel Price & Profitability & $\begin{array}{c}\text { Corporate Social } \\
\text { Responsibility }\end{array}$ \\
\hline Gasoline & 0.979 & & \\
Solar & 0.982 & 0.893 & \\
ROA & & 0.936 & \\
ROI & & 0.853 & \\
ROE & & & 0.836 \\
Environment & & 0.856 \\
Economics & & & \\
\hline
\end{tabular}

Source: SmartPLS version 3.0

Based on the above loading outer, most of the indicators or observed variables are significant, since the outer loading values are in accordance with the initial assumption. Discriminant validity reflective indicator can be seen on cross loading between indicator with its construct as follows:

Table 3. Cross Loadings

\begin{tabular}{lccc}
\hline & Oil fuel price & Profitability & $\begin{array}{c}\text { Corporate social } \\
\text { responsibility }\end{array}$ \\
\hline Gasoline & 0.979 & -0.154 & 0.156 \\
Solar & 0.982 & -0.205 & 0.115 \\
ROA & -0.099 & 0.893 & 0.253 \\
ROI & -0.157 & 0.936 & 0.219 \\
ROE & -0.219 & 0.853 & 0.266 \\
Environment & 0.129 & 0.220 & 0.836 \\
Economics & 0.105 & 0.249 & 0.856 \\
\hline
\end{tabular}

Source: SmartPLS version 3.0

In addition to the way in above, another method of assessing discriminant validity is to compare the square root of the average variance extracted (AVE) for each construct greater than the correlation between the construct and the other constructs in the model as shown below in the latent output of the correlation variable below:

Table 4. Latent Variable Correlations and Average Variance Extracted (AVE)

\begin{tabular}{lcccc}
\hline & Oil fuel price & Profitability & $\begin{array}{c}\text { Corporate social } \\
\text { responsibility }\end{array}$ & AVE \\
\hline Oil Fuel Price & 1,000 & \multirow{2}{*}{1,000} & 0.138 & 0.961 \\
Profitability & -0.184 & & 0.277 & 0800 \\
Corporate Social & & & 1,000 & 0.715 \\
Responsibility & & & & \\
\hline
\end{tabular}

Source: SmartPLS version 3.0

If the AVE square root value of each construct is greater than the correlation value between the construct and the other constructs in the model, it is said to have a good discriminant validity value. The model is said to be good if AVE shows a value greater than 0.50 looks like the output above, all constructs have a good realizability. So the model is fit with existing data.

\section{Indicator reability}

The limit value received for the Composite Realiability level is 70.7 , although it is not an absolute standard. Table 5 below provides the reliability composite value of the model 
Table 5. Composite Realiability

\begin{tabular}{lr}
\hline & Composite reliability \\
\hline Oil fuel price & 0.980 \\
Profitability & 0.923 \\
Corporate social responsibility & 0.834 \\
\hline Source: SmartPLS version 3.0 &
\end{tabular}

From Table 5, it can be seen that the Composite Reliability value of the three variables, namely the Fuel Oil Price of 0.980 is greater than the Profitability of 0.923 and the Corporate Social Responsibility of 0.834 . These three variables show a good value which is above 0.7 .

\section{Measurement model}

The measurement model determines the nature of the indicators of each latent variable, whether reflective or formative. Outer formative models are evaluated based on their substantive content by looking at the significance of weight (Table 6).

Table 6. Outer loadings (Mean, STDEV, T-Values, P-Values)

\begin{tabular}{lcrrrr}
\hline & $\begin{array}{c}\text { Original } \\
\text { Sample } \\
(\mathrm{O})\end{array}$ & $\begin{array}{c}\text { Sample } \\
\text { Mean } \\
(\mathrm{M})\end{array}$ & $\begin{array}{c}\text { Standard } \\
\text { Deviation } \\
(\mathrm{STDEV})\end{array}$ & $\begin{array}{c}\text { T Statistics } \\
(\mid \mathrm{O} / \mathrm{STDEV})\end{array}$ & P Values \\
\hline Gasoline <- Oil Fuel Price & 0.979 & 0.978 & 0.013 & 75.640 & 0.000 \\
Solar <- Oil Fuel Price & 0.982 & 0.980 & 0.012 & 80.679 & 0.000 \\
ROA<- Profitability & 0.893 & 0.882 & 0.150 & 5.949 & 0.000 \\
ROI <- Profitability & 0.936 & 0.923 & 0.131 & 7.133 & 0.000 \\
ROE<- Profitability & 0.853 & 0.835 & 0.122 & 6.971 & 0.000 \\
Enviroment <- CSR & 0.836 & 0.818 & 0.169 & 4.935 & 0.000 \\
Economy <- CSR & 0.856 & 0.807 & 0.188 & 4.562 & 0.000 \\
\hline
\end{tabular}

Source: SmartPLS versi 3.0

The measurement model seen from the value of the outer model above, all provide values that meet the criteria of the model. So that the measurement model can show indicators are valid.

\section{Structural model}

The relationship between latent variables (structural models), describes the relationship between latent variables based on the substantive theory.

Table 7. Path Coefficients (Mean, STDEV, T-Statistics, P-Value)

\begin{tabular}{lccccc}
\hline & $\begin{array}{c}\text { Original } \\
\text { Sample } \\
(\mathrm{O})\end{array}$ & $\begin{array}{c}\text { Sample } \\
\text { Mean (M) }\end{array}$ & $\begin{array}{c}\text { Standard } \\
\text { Deviation } \\
(\text { STDEV) }\end{array}$ & $\begin{array}{c}\text { T-Statistics } \\
(\mid \mathrm{O} / \\
\text { STDEV })\end{array}$ & $\begin{array}{c}\mathrm{P} \\
\text { Values }\end{array}$ \\
\hline Fuel Prices -> Profitability & -0.227 & -0.227 & 0.159 & 1.430 & 0.153 \\
Oil Fuel Price -> CSR & 0.138 & 0.146 & 0.183 & 0.752 & 0.452 \\
CSR -> Profitability & 0.309 & 0.326 & 0.145 & 2.127 & 0.034 \\
\hline
\end{tabular}

Source: SmartPLS version 3.0

Based on the above path coefficient (Table 7), we get the value of t-statistic and P-Value on each relationship between indicators. This result will determine the relationship between each variable.

Testing the path coefficient values is done by t-test. If the p-value is $\leq 0.05$ (alpha 5\%), then it is concluded that it is significant and vice versa. If the results of hypothesis testing on the outer model are significant, this indicates that the indicator can be used as a measuring instrument for latent variables. Furthermore, if the test results on 
the inner model are significant, it means that there is a significant influence between a latent variable on other latent variables.

\section{Discussion}

Based on the results of testing on Partial Least Square (PLS) method that has been described previously, then the discussion will be presented in two parts. The first part discusses the influence of fuel prices on profitability in the company of mining industry of oil and gas that are listed in the Indonesia Stock Exchange (BEI) in the period 2013 to 2016 and the second part discusses the influence corporate social responsibility (csr) as a moderating variable to the relation of oil fuel prices to profitability in the company and the same period.

\section{The effect of fuel price on profitability company}

From the results of analysis using SmartPLS with reflective measurement model as in Table 8, obtained value of $\mathrm{t}$-Statistics 1,430 and $\mathrm{P}$ - Value 0,153 with coefficient parameter $-0,227$ (negative). This shows that $\mathrm{T}-$ Statistics $<\mathrm{T}-\mathrm{Tables}(1,96)$ and $\mathrm{P}-$ Value $>\alpha(0.05)$ and positive. So it can be said that the price of fuel oil has no effect on profitability. The first hypothesis that the price of fuel oil has a significant effect on profitability is rejected.

Table 8. Path coefficients (Mean, STDEV, T-Values, P-Values)

\begin{tabular}{lccccc}
\hline & $\begin{array}{c}\text { Original } \\
\text { Sample } \\
(\mathrm{O})\end{array}$ & $\begin{array}{c}\text { Sample } \\
\text { Mean } \\
(\mathrm{M})\end{array}$ & $\begin{array}{c}\text { Standard } \\
\text { Deviation } \\
(\mathrm{STDEV})\end{array}$ & $\begin{array}{c}\text { T-Statistics } \\
(\mid \mathrm{O} / \\
\text { STDEV })\end{array}$ & $\begin{array}{c}\mathrm{P} \\
\text { Values }\end{array}$ \\
\hline Fuel Prices -> Profitability & -0.227 & -0.227 & 0.159 & 1.430 & 0.153 \\
\hline Source: SmartPLS version 3.0 & & & & &
\end{tabular}

This indicates that the company cannot respond to the event of a significant increase in fuel prices. So it can be said that the announcement of the increase or decrease in the price of fuel oil can not affect the profitability that can by the company.

Profitability shown by ROA, ROI, and ROE ratio shows the company's ability to generate income from asset management, investment, own capital, and public stock. This ratio shows how much the company's effectiveness in using its assets. The higher this ratio, the more effective the use of the asset.

The results of this study are not in line with research conducted by Sonya et al (2013) which states that changes in fuel prices have a significant effect on income levels on fishermen. The determinants of the price of oil follow the market economy, where the prevailing price level is determined by the demand and supply mechanism as a fundamental factor (Nizar, 2002). This certainly cannot be separated from the role of government as a holder of power and price policy makers can be more controlled by the government.

\section{The influence of corporate social responsibility (CSR) as a moderating variable on the relation of oil fuel price to profitability of oil and gas company}

From the analysis result using SmartPLS with reflective measurement model as in Table 9. obtained the relationship between the price of fuel oil to Corporate Social Responsibility with T-Statistics of $0.752(<1.96)$ and P-Value $0.452(>0.05)$. The value of the parameter coefficient is positive that is equal to 0.138 indicating that the direction of correlation between Fuel Price of Oil to Corporate Social Responsibility is positive. So it can be said price of fuel oil has no effect on Corporate Social Responsibility. 
Table 9. Path coefficients (Mean, STDEV, t-Values, P-Values)

\begin{tabular}{lccccc}
\hline & $\begin{array}{c}\text { Original } \\
\text { Sample } \\
(\mathrm{O})\end{array}$ & $\begin{array}{c}\text { Sample } \\
\text { Mean } \\
(\mathrm{M})\end{array}$ & $\begin{array}{c}\text { Standard } \\
\text { Deviation } \\
(\text { STDEV })\end{array}$ & $\begin{array}{c}\text { t- Statistics } \\
(\mid \mathrm{O} / \\
\text { STDEV })\end{array}$ & $\begin{array}{c}\mathrm{P} \\
\text { Values }\end{array}$ \\
\hline $\begin{array}{l}\text { Oil Fuel Price -> Corporate } \\
\text { Social Responsibility }\end{array}$ & 0.138 & 0.146 & 0.183 & 0.752 & 0.452 \\
$\begin{array}{l}\text { Corporate Social Responsibility - } \\
>\text { Profitability }\end{array}$ & 0.309 & 0.339 & 0.143 & 2.157 & 0.031 \\
\hline Source Smat
\end{tabular}

Source: SmartPLS version 3.0

Meanwhile, the relationship between Corporate Social Responsibility to Profitability is significant with t-Statistics of 2.157 ( $>1.96)$ and P-Value $0.031(<0.05)$. The value of the parameter coefficient is positive that is 0.309 indicating that the direction of the relationship between Corporate Social Responsibility to Profitability is positive. So it can be concluded that Corporate Social Responsibility effect on Profitability.

So, to prove the Corporate Social Responsibility can affect the relationship between the price of fuel oil to profitability is to multiply the value coefficient parameters of Fuel Oil Price to Corporate Social Responsibility of 0.138 with the value of the parameter of Corporate Social Responsibility to Profitability of 0.309 and produce a value of 0.043 indicating the relationship in a positive direction. Therefore it can be concluded that the second hypothesis states that Corporate Social Responsibility can affect the relationship of Fuel Price to Profitability but indirectly.

If the company cares for its economic and environmental concerns well, the people around the company will feel proud and motivated to participate in the conservation of the environment, but will also survive to use their products and realize the sustainable infrastructure and services that the company provides for the public interest resulting in a positive impact on the financial performance of the company.

The environmental performance indicator consists of several aspects, such as: material, energy, water, biodiversity, emission, effluent and waste aspects, product and service aspects, compliance aspects, transportation, and overall aspects. While indicators on economic performance consists of several aspects, including: aspects of economic performance, market presence aspects, and aspects of indirect impact.

The results are consistent with research conducted by Oktyas, et al (2015) which states that a lot of companies that have a progressive nature which are companies that implement Corporate Social Responsibility for promotional purposes da well as the empowerment. Promotion and Corporate Social Responsibility is seen as a useful activity and support each other for the progress of the company.

This form of Corporate Social Responsibility is also in accordance with stakeholder theory which states that the company is not an entity that only operates for its own sake, but must provide benefits to all its stakeholders (Chairi and Ghozali, 2009). Thus the existence of a company is strongly influenced by the support provided by stakeholders to the company.

\section{CONCLUSIONS AND RECOMMENDATIONS}

\section{Conclusion}

Based on the results of testing and discussion as has been presented in the previous section, it can be concluded that: 1) As the effect of the price of fuel oil to profitability consisting of Return on Assets (ROA), Return on Investment (ROI), and 
Return on Equity (ROE) implemented at oil and gas mining industry company listed in Indonesian Stock Exchange) period 2013 to 2016 based on test results through Partial Least Square (PLS ) proved to have no effect on Return on Assets (ROA), Return on Investment (ROI), and Return on Equity (ROE) which is part of profitability; 2) Corporate Social Responsibility (CSR) through indicators of environmental, economic, labor, human rights, social, and product performance based on test results through Partial Least Square (PLS) method indicates that there is indirectly positive influence on Corporate Social Responsibility (CSR) in moderating the relation of fuel price to the profitability of the company implemented in the oil and gas mining industry company listed in Indonesia Stock Exchange (IDX) period 2013 to 2016.

\section{Recommendations}

Recommendations given related to this research are among others: 1) This research is expected to be used as a reference for further research on the disclosure of Corporate Social Responsibility (CSR) by improving the existing limitations. Future research is expected to update the CSR disclosure index according to its research conditions, add broader corporate categories, increase the study period, and use new, more effective ways of measuring CSR disclosure; 2) Stimulus for the community to act as a controller of corporate behavior and remind the company of its social responsibility to the surrounding environment by implementing various useful activities; 3) For the government, it can be used as input material for making policy especially Directorate General of Oil and Gas in identifying its influence to company's revenue.

\section{BIBLIOGRAPHY}

Agustine, Ira. (2014). Pengaruh Corporate Social Responsibility Terhadap Nilai Perusahaan. Jurnal FINESTA Vol. 2, No. 1.

Ayu, Suwitho. (2015). Pengaruh Kinerja Keuangan Terhadap Nilai Perusahaan dengan Pengungkapan CSR Sebagai Variabel Moderating. Jurnal Ilmu dan Riset Manajemen 4. 4 April 2015.

Bambang, Melia. (2013). CSR- Corporate Social Responsibility Rekayasa Sains: Bandung.

Fahmi, Irham. (2012). Pengantar Manajemen Keuangan. Alfabeta: Jakarta.

Hasni, Yordi. (2013). Pengaruh Karakteristik Perusahaan Terhadap Pengungkapan CSR Perusahaan Pertambangan yang Tercatat Di Bursa Efek Indonesia. Jurnal Manajemen \& Bisnis Sriwijaya Vol.11. No.03/September 2013.

Husnan, Suad dan Pudjiastuti, Enny. (2004). Dasar-Dasar Manajemen Keuangan. Yogyakarta: UPP AMP YKPN.

Indriani, Rini dan Kamaludin. (2012). Manajemen Keuangan. CV. Mandar Maju: Bandung

Jessika, Hasan. (2014). Analisis Pengaruh Corporate Social Responsibility dan Profitabilitas Terhadap Nilai Perusahaan: Studi Empiris Pada Perusahaan Manufaktur yang Terdaftar di Bursa Efek Indonesia Tahun 2013. Jurnal Manajemen Vol.11. No.02/November 2014 : 38-55.

Latif, Abdul. (2015). Dampak Harga Bahan Bakar Minyak Terhadap Suplai Sembilan Bahan Pokok Di Pasar Tradisional. Journal.Iaingorontalo. Vol.11. No. 1 Juni 2015.

Nizar, A. Muhammad. (2012). The Impact of World Oil Prices Fluctuation on Indonesia's Economy. Pusat Kebijakan Ekonomi Makro. Badan Kebijakan Fiskal, Kementerian Keuangan-RI. Jakarta. 
Noor, Juliansyah. (2014). Analisis Data Penelitian Ekonomi dan Manajemen. Grasindo: Jakarta

Rahmawati, Setyaningtyas, Edy. (2014). The Effect of Corporate Social Responsibility on Financial Performance with Real Manipulation as a Moderating Variable.International Journal of Management, Economics and Social Sciences. Vol. 3(2), pp 59-78.

Ramadhan, Farid Siliwangi. (2013). Pengaruh Kenaikan Harga Bahan Bakar Minyak (BBM) Tahun 2013 Terhadap Investasi Saham. Fakultas Ekonomi Universitas Islam Indonesia, Yogyakarta

Robbins, Stephen P. (2010). Manajemen. Erlangga: Jakarta

Rohmah, Fauziyatur. (2014.) Analisis Penerapan Corporate Social Responsibility (CSR) Terhadap Profitabilitas Perusahaan. Universitas Negeri Surabaya

Rosiana, Gusti. (2013). Pengaruh Pengungkapan CSR Terhadap Nilai Perusahaan dengan Profitabilitas Sebagai Variabel Moderating. E-Jurnal Akuntansi Universitas Udayana 5.3 (2013):723-738.

Sanusi, Anwar. (2013). Metodologi Penelitian Bisnis. Salemba Empat: Jakarta.

Sonya, Debby, Daisy. (2013)..Analisis Pengaruh Harga Bahan Bakar Minyak dan Perubahan Cuaca Terhadap Pendapatan Nelayan di Kecamatan Tuminting Manado. Jurnal Ekonomi- Universitas Sam Ratulangi.

Sugiyono. (2014). Metode Penelitian Kuantitatif, Kualitatif, dan R\&D. Alfabeta: Bandung

Sutrisno. (2009). Manajemen Keuangan Teori, Konsep \& Aplikasi. Ekonisia: Yogyakarta.

Tukiran, Hidayati. (2014). Penelitian Kuantitatif (Sebuah Pengantar). Alfabeta: Bandung 